\title{
DNAJB1 Gene
}

National Cancer Institute

\section{Source}

National Cancer Institute. DNAIB1 Gene. NCI Thesaurus. Code C122560.

This gene plays a role in the regulation of protein folding. 